\title{
Influence of Trap Position with respect to Height and Placement Surface on Capture of the Tobacco Moth, Ephestia elutella (Hübner) (Lepidoptera: Pyralidae), in Pheromone Traps*
}

\author{
by \\ Toshihiro Imai ${ }^{1}$, Yoshihiro Kasaishi ${ }^{1}$ and Toshiro Fukushima ${ }^{2}$ \\ ${ }^{1}$ Leaf Tobacco Research Center, Japan Tobacco Inc., Oyama, Tochigi 323-0808, Japan \\ ${ }^{2}$ Central Tobacco Research Center, Japan Tobacco Inc., Yokohama, Kanagawa 227-8512, Japan
}

\section{SUMMARY}

The efficacy of pheromone traps is affected by trap placement and pest biology, as well as by the trap and lure design. We evaluated the effect of trap height and placement in relation to surfaces on tobacco moth catches using release-capture experiments. Six traps were mounted vertically in a $9 \times 15 \times 4.2-5.8 \mathrm{~m}$ shed on a wall at heights of $0,1,2,3,4$ and $5 \mathrm{~m}$. More catches were obtained near the ceiling and at $1 \mathrm{~m}$ above the floor in the dark. Catches at $1 \mathrm{~m}$ were negligible when light shone through the upper windows. In a $42.3 \times 36.5 \times 4 \mathrm{~m}$ tobacco warehouse, the respective efficacies of aerially suspended traps and surface-mounted traps were examined. The number of catches obtained using traps mounted on pillars was significantly higher than that obtained in traps suspended from poles. These results suggest practical considerations for monitoring in warehouses. We recommend eliminating any night lighting and placing traps on surfaces, such as walls and stored commodities, at higher positions that are within reach $(1 \mathrm{~m})$ to facilitate convenient inspection. [Beitr. Tabakforsch. Int. 24 (2010) 29-32]

\section{ZUSAMMENFASSUNG}

Die Effektivität von Pheromonfallen wird von der Position der Falle und der Biologie des Schädlings beeinflusst, aber auch vom Design der Falle und des Lockmittels. Wir haben mit Hilfe von „Release-Capture“-Experimenten den Einfluss der Höhe der Falle und der Position in Bezug zur Oberfläche auf die Anzahl der gefangenen Tabakmotten untersucht. Sechs Fallen wurden vertikal an die Wände eines $9 \times 15 \mathrm{~m}$ großen Lagerhauses mit 4,2 bzw. 5,8 m hohen Wänden in $0,1,2,3,4$ und $5 \mathrm{~m}$ Höhe angebracht. Die meisten Motten wurden in der Nähe des Daches und in $1 \mathrm{~m}$ Höhe über dem Boden bei Dunkelheit gefangen. Wenn Licht durch die oberen Fenster schien, war die Ausbeute in $1 \mathrm{~m}$ Höhe vernachlässigbar. Entsprechend wurde bei einem 42,3 $\times 36,5 \times 4 \mathrm{~m}$ großen Tabaklagergebäude die Effektivität von frei hängenden Fallen gegenüber Fallen, die auf Oberflächen montiert waren, untersucht. Die Anzahl der gefangenen Motten bei den auf den Pfeilern montierten Fallen war signifikant höher als bei den Fallen, die frei von den Pfeilern herabhingen. Diese Ergebnisse geben praktische Hinweise für das Monitoring in Tabaklagergebäuden. Empfohlen wird, sämtliche Lichtquellen in der Nacht zu eliminieren, sowie die Fallen auf Oberflächen, wie Mauern oder den gelagerten Rohstoffen etwas erhöht $(1 \mathrm{~m})$ zu platzieren, um eine zweckmäßige Inspektion zu erleichtern. [Beitr. Tabakforsch. Int. 24 (2010) 29-32]

\section{RESUME}

L'efficacité des pièges à phéromones dépend de leur positionnement et de la biologie des parasites ainsi que de 
la conception du piège et de celle du leurre. Nous avons évalué les effets de la hauteur et du positionnement du piège par rapport aux surfaces sur le piégeage de la teigne du tabac en utilisant des essais de libération-capture. Six pièges ont été montés verticalement dans un abri de $9 \times 15 \times 4.2-5.8 \mathrm{~m}$ sur un mur à une hauteur de $0,1,2,3$, 4 et $5 \mathrm{~m}$ respectivement. Le nombre de captures était plus important près du plafond et à $1 \mathrm{~m}$ du sol dans l'obscurité. Les captures étaient négligeables à $1 \mathrm{~m}$ de hauteur quand la lumière passait à travers les fenêtres supérieures. Dans un entrepôt de tabac de $42,3 \times 36,5 \times 4 \mathrm{~m}$, les efficacités respectives de pièges suspendus dans l'air et de pièges montés en surface ont été étudiées. Le nombre de captures obtenues en utilisant des pièges montés sur des piliers était significativement supérieur à celui obtenu dans des pièges suspendus à des piquets. Ces résultats impliquent des considérations pratiques pour le contrôle en entrepôt. Nous recommandons de supprimer tout éclairage nocturne et de placer les pièges sur des surfaces telles que des murs et des marchandises entreposées, à des positions surélevées qui soient accessibles $(1 \mathrm{~m})$ pour faciliter l'inspection. [Beitr. Tabakforsch. Int 24 (2010) 29-32]

\section{INTRODUCTION}

The tobacco moth, Ephestia elutella, is a major pest of stored tobacco in temperate regions throughout the world. The larvae feed on a wide range of dry plant materials, including flue-cured tobacco, cacao, cereals, dried fruits and vegetables, nuts, seeds and other botanicals (1-4). In Japan, the occurrence of this pest in tobacco farm storages, warehouses and cigarette manufacturing factories was consistently recorded until the 1980 s $(5,6)$, but we know of no reports since that time. However, the risk of infestation has been growing because of increasing international supplies of leaf tobacco obtained from infested areas. This pest is susceptible to insecticides that are applied to tobacco, including pyrethroids and phosphine, and it can be controlled through the use of these chemicals. Therefore, detection of immigration and early infestation plays an important role in controlling the spreading of this pest in tobacco facilities in Japan. Commercial pheromone traps for this pest have been used for monitoring, but factors that influence trapping efficiency have not been adequately considered. The trap catch is affected by trap placement and pest biology, as well as by the design of traps and lures (7). Such factors may result in misinterpretation of trap catches and failed detection. The influence of trap design and placement on trapping efficiency has been intensively studied for the Indian meal moth, Plodia interpunctella $(8-10)$, which is closely related to the tobacco moth. The pheromones of these two species share the same components (11-13). For the tobacco moth, comparative evaluation of several types of traps has been performed (14), but little is known about the effect of trap placement on the catch. The present study evaluated the effects of trap height and placement on tobacco moth catches in an attempt to ensure trapping efficacy and standardize trap-monitoring procedures for this pest in tobacco warehouses.

\section{MATERIALS AND METHODS}

Insects

The tobacco moths used in this study were obtained from our laboratory culture maintained on $10 \%$ yeast-enhanced corn flour at $27{ }^{\circ} \mathrm{C}$ and $60 \%$ relative humidity. Unmated males collected immediately after emergence were maintained for 1-3 days under rearing conditions and then used for testing.

\section{Pheromone trap}

Commercial pheromone traps (Fuji Trap Gachon; Fuji Flavor Co. Ltd., Tokyo) were used for all experiments. The trap has a half-cylindrical shape (sides with D-shape openings) with an interior sticky surface (Fig. 1). It can be closely fitted to a flat surface.

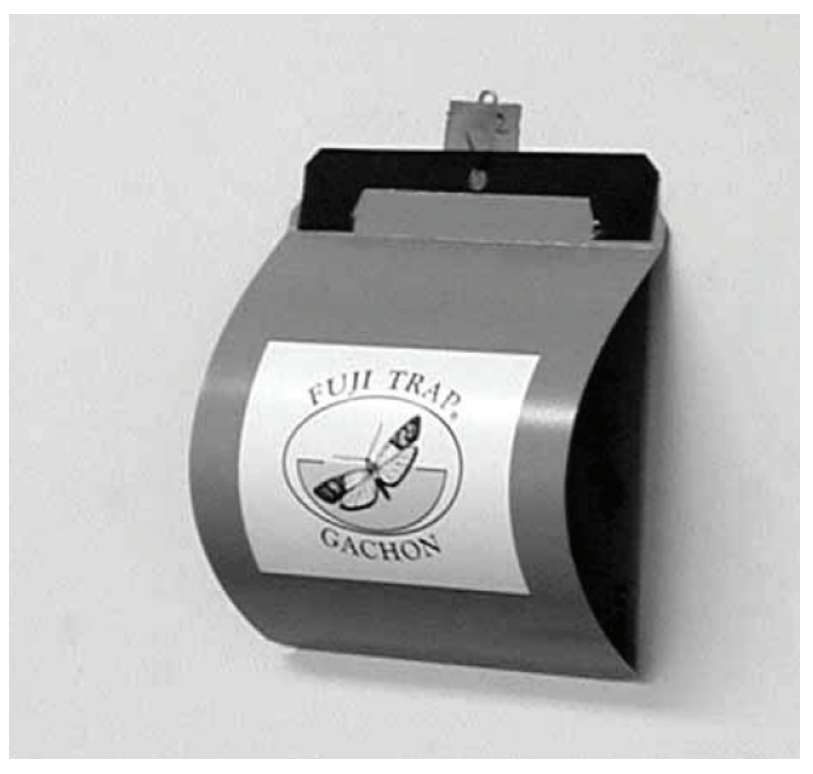

Figure 1. Pheromone traps used in tests (Fuji Trap Gachon, Fuji Flavor Co. Ltd., Tokyo)

\section{Experiment 1: Evaluation of trap height}

The effect of trap height was evaluated in a $9 \times 15 \mathrm{~m}$ shed used for storing farm machines and implements. The sidewalls were $4.2 \mathrm{~m}$ in height, with glass windows aligned at a height of 2.5-3.2 m. The ceiling of the shed reached $5.8 \mathrm{~m}$ above the ground in the room's center. Sunlight shone through the windows during the day, and continuous light from outdoor lamps was present at night. The windows were covered with aluminum foil to achieve dark conditions when necessary. Six traps were mounted on a wall, with their flat surface fitted to the wall at heights of $0,1,2,3,4$ and $5 \mathrm{~m}$. One hundred males were released from the floor, $3 \mathrm{~m}$ from the wall. Trap catches were counted two or three days after release. Five replicates were performed continuously, without recovering the untrapped males from preceding tests. The temperatures were uncontrolled, varying from $18.4^{\circ} \mathrm{C}$ to $32.6^{\circ} \mathrm{C}$ during the test. 


\section{Experiment 2: Evaluation of trap placement}

The efficacies of surface-mounted traps and aerialsuspended traps were evaluated separately in a $42.3 \times 36.5 \times 4 \mathrm{~m}$ tobacco warehouse compartment in which tobacco dust was stored in flexible bags and piles of pallets. Pillars (vertical beams) were present at intervals of $6 \mathrm{~m}$ for the entire length of the room $(8 \times 7=56$ pillars $)$. Sunlight shone through windows onto the walls, but no lighting was present during the night. The absence of tobacco moths in the room was confirmed by pheromone trap monitoring prior to the test. In the first trial, four traps arranged in a grid $(18 \times 24 \mathrm{~m})$ were mounted on pillars, and in the second trial they were suspended from poles standing $30 \mathrm{~cm}$ away from the respective pillars at a height of $2 \mathrm{~m}$. Two hundred males were released in the middle of the floor; trap catches were counted 7 days after release. The tests were duplicated for each placement. Temperatures were not controlled and varied from $25.1{ }^{\circ} \mathrm{C}$ to $31.9{ }^{\circ} \mathrm{C}$ during the test.

\section{Statistical analyses}

Statistical analyses were performed using SPSS 10.0 software (SPSS Inc., Chicago, IL). Capture data were transformed to $\log (x+0.5)$ to normalize variances. Means were compared using Tukey's HSD multiple test and $t$-test for Experiments 1 and 2, respectively.

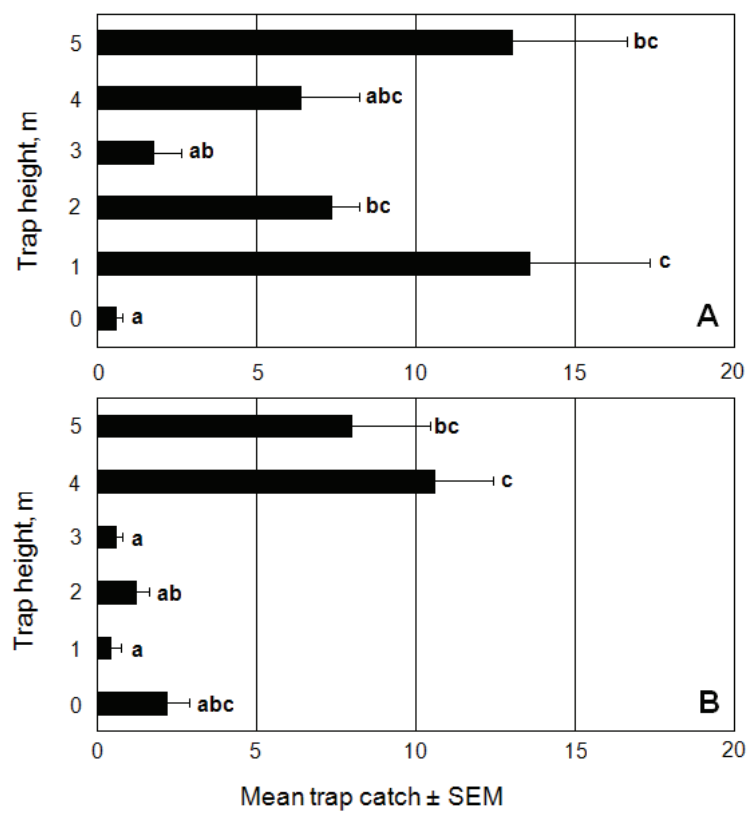

Figure 2. Catches of the tobacco moth at six heights under dark conditions (A: upper) and with lighting from upper windows (B: lower). Columns represent mean catches with SEM bars $(N=5)$. Columns with identical letters are not significantly different according to Tukey's HSD test $(p<0.05)$.

\section{RESULTS AND DISCUSSION}

Trap catches according height are shown in Figure 2. Traps near the ceiling caught larger numbers of moths, irrespective of light conditions. The effect of lighting varied at different heights.

Under dark conditions, larger catches were obtained using traps positioned $1 \mathrm{~m}$ above the floor, as well as in traps near the ceiling (Fig. 2A). On the other hand, when light shone through the windows onto the upper walls, catches at $1 \mathrm{~m}$ were negligible and the number of catches in traps at $4 \mathrm{~m}$ increased (Fig. 2B). The adults of this species exhibit positive phototaxis and are frequently captured by light traps $(14,15)$. Such bias in trap catches under different lighting conditions may be due to the phototactic behavior of this species. The effects of trap height on catch have been reported for the Indian meal moth $(10,16)$. VICK et al. (16) found no significant differences in trap catches at 2, 5 and $10 \mathrm{~m}$, whereas NANSEN et al. (10) detected higher catches near ceilings and floors using traps hung from vertical strings at least $3 \mathrm{~m}$ away from walls and no significant difference among heights when traps were placed along the walls. They suggested a crucial role of a physical surface, such as a floor and ceiling, on effective trapping of the Indian meal moth (10). Our findings regarding tobacco moth catches at various heights were obtained using traps mounted on walls. Difference in catches at various heights may be due to the flight behavior of this species. Furthermore, any surface effects due to the floor or ceiling should be decreased by the presence of a wall around each trap.

The surface effect as related to the tobacco moth catch is revealed in Experiment 2 (Table 1). For the Indian meal moth, NANSEN et al. (10) reported that the presence of landing space facilitates courtship behavior and thereby improves trap catches. The courtship behaviors of "storedproduct complex of phycitine moths" including the Indian meal moth and tobacco moth, are described as virtually identical: courtship begins as a male approaches a pheromone-emitting female while exhibiting wing-fanning and exposing scent scales on the forewing costal margin (17). We observed that tobacco moths approached and entered the traps after landing on the outer surface of the trap or on a nearby wall, while exhibiting wing-fanning as a normal courtship behavior. This observation suggests that surface mounting is more advantageous for the tobacco moth trapping than aerial hanging because of the presence of a larger landing space around the trap.

Table 1. Catches of the tobacco moth by wall-mounted traps and aerially suspended traps. Four traps arranged in an $18 \times 24 \mathrm{~m}$ grid were placed on pillars or suspended from poles at $2 \mathrm{~m}$ height, then 200 males were released from the center. Tests were conducted twice for each placement.

\begin{tabular}{l|c|c}
\hline Placement & Mean $\pm \mathrm{SEM}^{*}$ & $p^{*}$ \\
\hline Wall-mounted & $28.8 \pm 6.2$ & 0.0337 \\
Suspended & $18.5 \pm 5.8$ & 0.8 \\
\hline
\end{tabular}

*Means were compared using $t$-test $(N=8)$.

Monitoring data obtained using pheromone traps are used for detection, threshold notice, density estimation and spatial analysis $(7,18,19)$. Variations in trapping efficacy that are attributable to inconsistent operating procedures might lead to misinterpretation of the trapping data. The results of the present study reveal the significant influence 
of trap height, placement, and lighting on the efficacy of traps and elucidate practical factors that should be considered when monitoring the tobacco moth. We recommend placing traps on surfaces, such as walls, pillars and stored commodities, as well as eliminating night lighting. Trap placement at higher positions within reach $(1 \mathrm{~m})$ is preferable for convenient inspection.

\section{REFERENCES}

1. Takaoka, I. and K. Nakazawa: Studies on insects attacking stored tobacco and tobacco products. I. External Morphology, seasonal occurrence and habits of tobacco moth, Ephestia elutella Hübner [in Japanese with English summary]; Bull. Hatano Tob. Exp. Sta. 41 (1956) 1-16.

2. Ashworth, J.R.: The biology of Ephestia elutella.; J. Stored Prod. Res. 29 (1993) 199-205.

3. Ryan, L. (ed.): Post-harvest tobacco infestation control; Kluwer Academic Publishers, Dordrecht, 1999, 155 pp.

4. Arbogast, R.T., P.E. Kendra, and R.C. McDonald: Infestation of a botanicals warehouse by Plodia interpunctella and Ephestia elutella (Lepidoptera: Pyralidae); Entomol. News 113 (2002) 41-49.

5. Tamura, M: Studies on occurrence of stored tobacco pests in tobacco factories 1-2 [in Japanese]; Special Bull. Hatano Tob. Exp. Sta. 8 (1971) 225-314.

6. Koizumi, S., H. Kikukawa, and C. Shimoji: Occurrence and ecology of pests attacking stored tobacco in growing districts in Kyushu [in Japanese with English summary]; Bull. Kagoshima Tob. Exp. Sta. 26 (1985) 75-86.

7. Jones, O.T.: Pest monitoring; in: Insect pheromones and their use in pest management, edited by P. Howse, J. Stevens, and O. T. Jones; Chapman \& Hall, London, 1998, pp. 263-279.

8. Mullen, M.A. and A.K. Dowdy: A pheromone-baited trap for monitoring the Indian meal moth, Plodia interpunctella (Hübner) (Lepidoptera: Pyralidae); J. Stored Prod. Res. 37 (2001) 231-235.

9. Mullen, M.A., E.P. Wileyto, and F.H. Arthur: Influence of trap design and location on the capture of Plodia interpunctella (Indian meal moth) (Lepidoptera: Pyralidae) in a release-recapture study; J. Stored Prod. Res. 34 (1997) 33-36.

10. Nansen, C., T.W. Phillips, and S. Sanders: Effects of height and adjacent surfaces on captures of Indian meal moth (Lepidoptera: Pyralidae) in Pheromone- baited traps; J. Econ. Entomol. 97 (2004) 1284-1290.

11. Kuwahara, Y. and J.E. Casida: Quantitative analysis of the sex pheromone of several phycitid moths by electron-capture gas chromatography; Agric. Biol. Chem. 37 (1973) 681-684.

12. Krasnoff, S.B., K.W. Vick, and J.A. Coffelt: $(Z, E)-$ 9,12-Tetradecadien-1-ol: A component of the sex pheromone of Ephestia elutella (Hübner) (Lepidoptera: Pyralidae); Environ. Entomol. 13 (1984) 765-767.

13. Zhu, J., C. Ryne, C.R. Unelius, P.G. Valeur, and C. Löfstedt: Reidentification of the female sex pheromone of the Indian meal moth, Plodia interpunctella: Evidence for a four-component pheromone blend; Entomol. Exp. Appl. 92 (1999) 137-146.

14. Genève, R., R. Delon, F. Fleurat-Lessard, D. Hicaubé, and J.M. Le Torc'h: Comparaison de différents types de pièges à phéromone pour le suivi de la présence d'EPHESTIA ELUTELLA (Hübner) (Lep. Pyralidae) dans les locaux de stockage de tabac; Ann. du Tabac SEITA - Les Aubrais - Sect. 119 (1990) 65-77.

15. Waloff, N. and O.W. Richards: Observation on the behaviour of Ephestia elutella (Hübner) (Lep., Phycitidae) breeding on bulk grain; Trans. R. Entomol. Soc. London 97 (1946) 299-335.

16. Vick, K.W., P.G. Koehler, and J J. Neal: Incidence of stored-product Phycitinae moths in food distribution warehouses as determined by sex pheromone-baited traps; J. Econ. Entomol. 79 (1986) 936-939.

17. Phelan, P.L. and T.C. Baker: Comparative study of courtship in twelve phycitine moths (Lepidoptera: Pyralidae); J. Insect Behav. 3 (1990) 303-326.

18. Wall, C.: Principles of monitoring; in: Behaviormodifying chemicals for insect management, edited by R.L. Ridgway, R.M. Silverstein, and M.N. Inscoe; Marcel Dekker, Inc., New York, 1990, pp. 9-23.

19. Fields, P.G. and N.D.G. White: Alternatives to methyl bromide treatments for stored-product and quarantine insects; Ann. Rev. Entomol. 47 (2002) 331-359.

\section{Corresponding author:}

\section{Toshihiro Imai}

Leaf Tobacco Research Center

Japan Tobacco Inc.

Idei 1900, Oyama,

Tochigi 323-0808, Japan

E-mail: toshihiro.imai@jt.com 